Sharif University of Technology
Scientia Iranica
Transactions A: Civil Engineering
SCIENTIA $\quad \begin{aligned} & \text { http://scientiairanica.sharif.edu } \\ & \text { IRAN ICA }\end{aligned}$

\title{
Suitability of brick kiln waste as a stabilizer for clayey soils
}

\author{
A. Saand ${ }^{a}$, M.A. Zardari ${ }^{a, *}$, M.A. Keerio ${ }^{b}$, S.H. Shaikh ${ }^{c}$, and D.K. Bangwar \\ a. Department of Civil Engineering, Quaid-e-Awam University of Engineering, Science and Technology, Nawabshah, Sindh, \\ Pakistan. \\ b. Department of Civil Engineering, Quaid-e-Awam University College of Engineering, Science and Technology, Larkano, Sindh, \\ Pakistan. \\ c. Architecture and Engineering Services for Sindh Basic Education Program-II, Halcrow Pakistan, Pvt. Ltd, House No. C-172, \\ Block C, Government Employees Cooperative Housing Society, Sukkur, Sindh, Pakistan.
}

Received 6 January 2018; received in revised form 28 June 2018; accepted 22 October 2018

\section{KEYWORDS}

Clayey soil;

Brick kiln waste;

Stabilizer;

Bearing capacity;

Dry density;

Cohesion;

Friction angle.

\begin{abstract}
Due to the growing use of brick masonry for the construction of buildings in Pakistan, huge quantities of Brick Kiln Waste (BKW) are generated which can not only create disposal problems but are hazardous to the environment. In order to resolve such problems, it is necessary to investigate the suitability of the BKW as a stabilizer for the clayey soils. For this purpose, an experimental program was carried out to stabilize clayey soil with the BKW ranging from 5 to $40 \%$. Basic geotechnical tests were performed on the clayey soil blended with the BKW. The results showed that the clayey soil became coarser and more suitable as a subgrade material with the addition of the BKW. There was a negligible reduction in dry density up to $7 \%$ when the BKW added was $40 \%$. As expected, the cohesion and friction angle of the blended soils decreased and increased, respectively, with the inclusion of the BKW. As compared to the clayey soil, the ultimate bearing capacity of the blended soil, characterized by $40 \%$ of the BKW, increased by $21 \%$. This study showed that clayey soils stabilized with BKW could be used as a partial fill material for highway embankments and foundations of buildings.
\end{abstract}

(C) 2020 Sharif University of Technology. All rights reserved.

\section{Introduction}

Presently, fired bricks are widely used for constructing buildings. Due to a constant increase in the population of Pakistan, there is more demand for houses. To meet demand for houses, bricks are manufactured on a large scale. In Pakistan, approximately 18000 kilns are in operation which fire about 45 billion bricks

\footnotetext{
*. Corresponding author. Tel.: 00923331225200

E-mail addresses: abdullah.saand@gmail.com (A. Saand); muhammad.auchar@quest.edu.pk (M.A. Zardari); mantharali99@quest.edu.pk (M.A. Keerio); sabir.hussain@halcrowpk.com (S.H. Shaikh); daddan@quest.edu.pk (D.K.Bangwar)
}

doi: $10.24200 /$ sci.2018.50198.1569 annually [1]. The fuel used for firing bricks in kilns consists of wood and agricultural by-products such as rice husk, sugarcane bagasse, old pieces of clothes, etc. As a result, a huge quantity of waste consisting of ash and small pieces of bricks is generated on sites where kilns are located. The Brick Kiln Waste (BKW) is not disposed of properly, which is a current practice in Pakistan. The BKW gradually accumulates on the sites of the kilns. The accumulated BKW may create not only disposal but environmental problems. To alleviate these problems, it is necessary to investigate whether the BKW can be used as a stabilizer for clayey soils, which are considered as poor material for various civil engineering works.

Highway embankments and foundations of buildings require massive quantities of fill materials. The 
clayey soils may exhibit low bearing capacity, high compressibility, and settlement. As a result, the pavements of roads may experience cracks and buildings may suffer from differential settlement, which may reduce their service life. Under these conditions, the clayey soils may be stabilized with granular soils to achieve satisfactory performance. The use of the BKW as a partial fill material with clayey soils in highway embankments and foundations of buildings could be a better option than disposal, which is costly.

Throughout the world, billions of tons of solid waste are generated annually. Efforts are being made to implement waste management practices to reduce the environmental problems of solid wastes [2-4]. Nowadays, solid wastes are utilized in various civil engineering domains such as soil stabilization [5-8] and landfills $[9,10]$. Fly ash has been utilized as a partial fill material in highway embankments [11-14]. Rice husk ash is also used as a partial construction material in highways [15-17]. Waste ceramic dust [18], marble dust [19], and brick dust [20] have also been utilized for soil stabilization. The authors are of the view that no study has been published on the suitability of BKW as a stabilizer for civil engineering construction projects. The purpose of this study is to assess the viability of the BKW as a partial fill material for the construction of highway embankments and foundations of buildings. For this purpose, index properties, compaction, shear strength parameters, and ultimate bearing capacity of the clayey soil partially blended with the BKW are determined.

\section{Materials and methods}

\subsection{Materials}

Clayey soil samples were excavated from areas close to Nawabshah city. The BKW was obtained from a local brick kiln in the surrounding area of Nawabshah city (Figure 1). The BKW consists of ash of rice husk and wood and small pieces of broken bricks, which were finer than Sieve 4. The larger pieces of the bricks were broken and made finer than Sieve 4 . The BKW was mixed with the clayey soil with an increment of $5 \%$ by

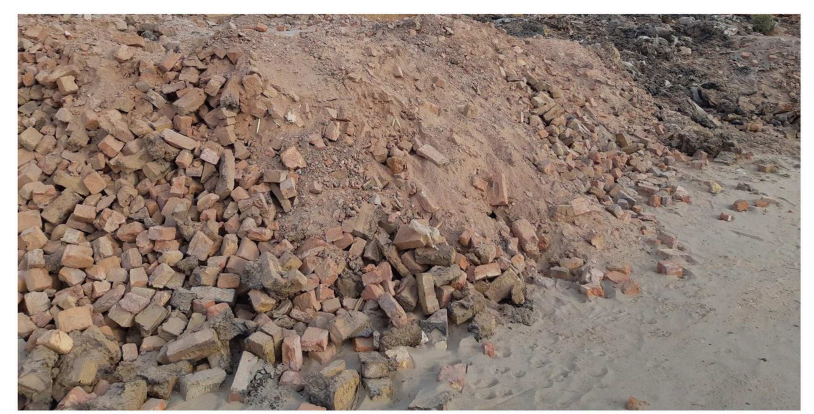

Figure 1. A view of brick kiln waste generated by a local brick manufacturing work. weight. This mixing process of the BKW with clayey soil increased up to $40 \%$.

\subsection{Testing program}

The particle-size distribution curves of the soils were evaluated using ASTM D422 [21]. Liquid and plastic limits were determined with ASTM D4318 [22]. The soils were classified according to AASHTO classification system [23]. Moisture density relationship and shear strength parameters of the soils were evaluated using references ASTM D1557-12 [24] and ASTM D3080/D3080M-11 [25], respectively. Free swell ratio of the soils was determined using a procedure described by Prakash and Sridharan [26].

\section{Results and discussion}

\subsection{Liquid limit, plastic limit, and plasticity index of the soils}

Table 1 shows the values of plastic limit, liquid limit, and plasticity index of all soil samples. As expected, the values of the above-mentioned parameters of the blended soils decreased with an increase in content of the BKW. As compared to the clayey soil, the values of the liquid limit, plastic limit, and plasticity index of the blended soil having $40 \%$ BKW were reduced by $27 \%, 28 \%$, and $11 \%$, respectively. The decrease of consistency values of blended soils results from an increase in coarse particles of the BKW.

\subsection{Classification}

The particle-size distribution curves of the clayey soil mixtures blended with various proportions of the BKW are presented in Figure 2. It can be observed that particle sizes of clay and the BKW range from $2 \mathrm{~mm}$ to $0.01 \mathrm{~mm}$ and from $4.75 \mathrm{~mm}$ to $0.01 \mathrm{~mm}$, respectively. For all mixes, the soils are well graded. The original soil is classified as A-7-5 group (clayey soil), which is considered as a poor soil. The blended soil was improved into A-4 (silty soil) and A-2-4 (silty or clayey gravel and sand) groups, when the BKW was increased

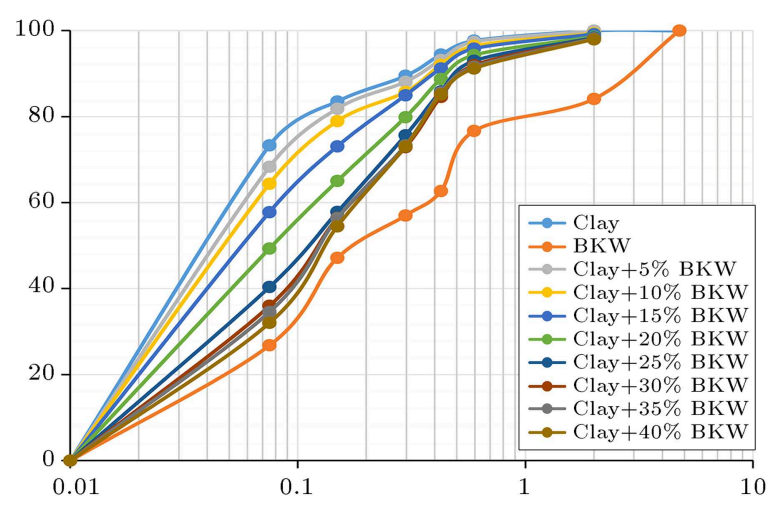

Figure 2. Particle size distribution curves of soils blended with 5 to $40 \%$ Brick Kiln Waste (BKW). 
Table 1. Index properties of the clayey soil blended with Brick Kiln Waste (BKW).

\begin{tabular}{|c|c|c|c|c|c|c|}
\hline Serial no. & Soil mixture & $\begin{array}{c}\text { Liquid } \\
\text { limit } \\
(\%)\end{array}$ & $\begin{array}{c}\text { Plastic } \\
\text { limit } \\
(\%)\end{array}$ & $\begin{array}{c}\text { Plasticity } \\
\text { index } \\
(\%)\end{array}$ & $\begin{array}{c}\text { passing } \\
\text { from } \\
\text { \#200 sieve }(\%)\end{array}$ & $\begin{array}{c}\text { AASHTO } \\
\text { classification }\end{array}$ \\
\hline 1 & Clay & 47 & 35 & 12 & 73 & $A-7-5$ \\
\hline 2 & Brick Kiln Waste (BKW) & 21 & 19 & 2 & 26 & A-2-4 \\
\hline 3 & Clay $+5 \%$ BKW & 45 & 34 & 11 & 68 & $A-7-5$ \\
\hline 4 & Clay $+10 \%$ BKW & 44 & 33 & 11 & 64 & $A-5$ \\
\hline 5 & Clay $+15 \%$ BKW & 42 & 33 & 9 & 57 & $A-5$ \\
\hline 6 & Clay $+20 \%$ BKW & 40 & 30 & 10 & 49 & $A-5$ \\
\hline 7 & Clay $+25 \%$ BKW & 39 & 29 & 10 & 40 & $A-4$ \\
\hline 8 & Clay $+30 \%$ BKW & 38 & 29 & 9 & 36 & $\mathrm{~A}-4$ \\
\hline 9 & Clay $+35 \%$ BKW & 37 & 28 & 9 & 34 & $A-2-4$ \\
\hline 10 & Clay $+40 \%$ BKW & 34 & 25 & 9 & 32 & $\mathrm{~A}-2-4$ \\
\hline
\end{tabular}

from $10 \%$ to $30 \%$ and $35 \%$ to $40 \%$. This implies that the blended soil became coarser with an increase in the BKW than the clayey material. According to AASHTO classification system, the A-7-5 and A-2-4 groups represent the poor- and good-quality subgrade soils, respectively. A-2-4 soils are appropriate material for the construction of embankments. Soils belonging to A-4 group can also be used as a fill material for lowheight embankments in those locations where moisture is not expected to increase above the placement water content (see, e.g., [27]).

\subsection{Effect of BKW on moisture-density relationship of soils}

Modified Proctor compaction tests were carried out on soil samples that contained clay, BKW, and blended soils. The Optimum Moisture Content (OMC) and the maximum dry density values of the blended soils were evaluated (Figure 3). The values of OMC increased, and the dry density decreased with increase in the BKW (Table 2). This is because the BKW is a porous material, which absorbed more water, thus

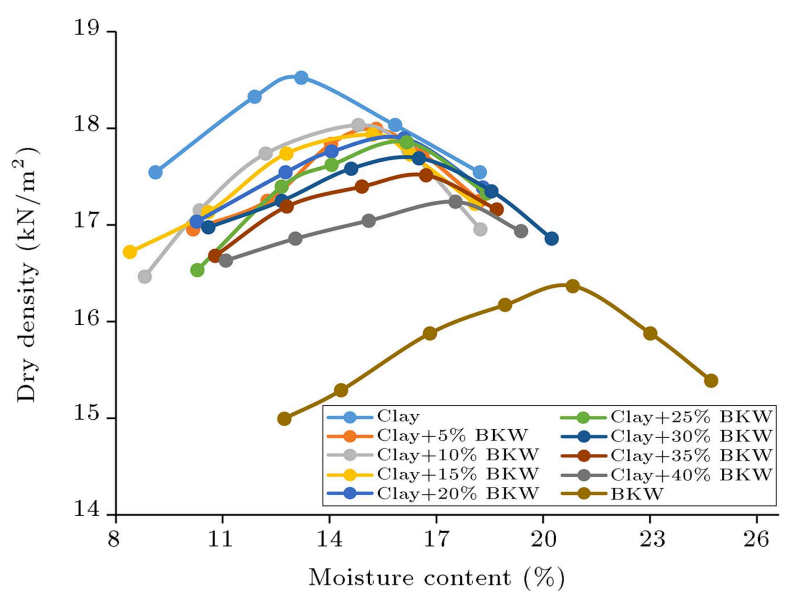

Figure 3. Moisture density relationship of the soils mixed with 5 to $40 \%$ Brik Kiln Waste (BKW).

increasing the $\mathrm{OMC}$ and reducing the dry density. The values of dry density of the clay slightly reduced from $18.5 \mathrm{kN} / \mathrm{m}^{3}$ to $17.9 \mathrm{kN} / \mathrm{m}^{3}$ and $17.2 \mathrm{kN} / \mathrm{m}^{3}$ when it blended with $5 \%$ and $40 \%$ of the BKW. The values of the dry density of the blended soils are comparable to

Table 2. Optimum moisture content and maximum dry density values of the soil mixed with different proportions of the Brick Kiln Waste (BKW).

\begin{tabular}{|c|c|c|c|c|c|}
\hline Serial no & Soil mixture & $\begin{array}{c}\text { OMC } \\
(\%)\end{array}$ & $\begin{array}{c}\text { Increase in } \\
\text { OMC }(\%) \text { as } \\
\text { compared to clay }\end{array}$ & $\begin{array}{l}\text { Dry density } \\
\qquad\left(\mathrm{kN} / \mathbf{m}^{3}\right)\end{array}$ & $\begin{array}{l}\text { Decrease in dry } \\
\text { density (\%) as } \\
\text { compared to clay }\end{array}$ \\
\hline 1 & Clay & 13 & - & 18.5 & - \\
\hline 2 & Brick Kiln Waste (BKW) & 20 & - & 16.4 & - \\
\hline 3 & Clay $+5 \%$ BKW & 15 & 15 & 17.9 & 3 \\
\hline 4 & Clay $+10 \%$ BKW & 15 & 15 & 18 & 3 \\
\hline 5 & Clay $+15 \%$ BKW & 15 & 15 & 17.9 & 3 \\
\hline 6 & Clay $+20 \%$ BKW & 16 & 23 & 17.9 & 3 \\
\hline 7 & Clay $+25 \%$ BKW & 16 & 23 & 17.8 & 4 \\
\hline 8 & Clay $+30 \%$ BKW & 16.5 & 26 & 17.7 & 4 \\
\hline 9 & Clay $+35 \%$ BKW & 16.7 & 28 & 17.5 & 5 \\
\hline 10 & Clay $+40 \%$ BKW & 17.6 & 35 & 17.2 & 7 \\
\hline
\end{tabular}


those of a mixture of sand and gravel and well-graded sands (see, e.g., [28]).

It is to be noted that maximum reduction in the value of dry density of the blended soil was $7 \%$ when the BKW added was $40 \%$. This implies that if the BKW is available in large volumes, it can be utilized by as high as $40 \%$ with clayey soil without affecting dry density.

\subsection{Effect of $B K W$ on shear strength parameters of the soil}

Shear strength parameters (cohesion and friction angle) of the clayey soil mixed with different percentages of the BKW were determined through shear box tests. The cohesion of the blended soils decreased (Figure 4) and the friction angle increased (Figure 5) with an increase in the BKW. The cohesion and friction angle values of the blended soils were decreased by $40 \%$ and increased by $38 \%$, respectively, when the BKW added was $40 \%$. This is because the blended soils contained coarse and angular particles of the BKW.

\subsection{Effect of the $B K W$ on ultimate bearing capacity of clayey soil}

In order to find the potential of the clayey soils stabilized with the BKW, the bearing capacity of an

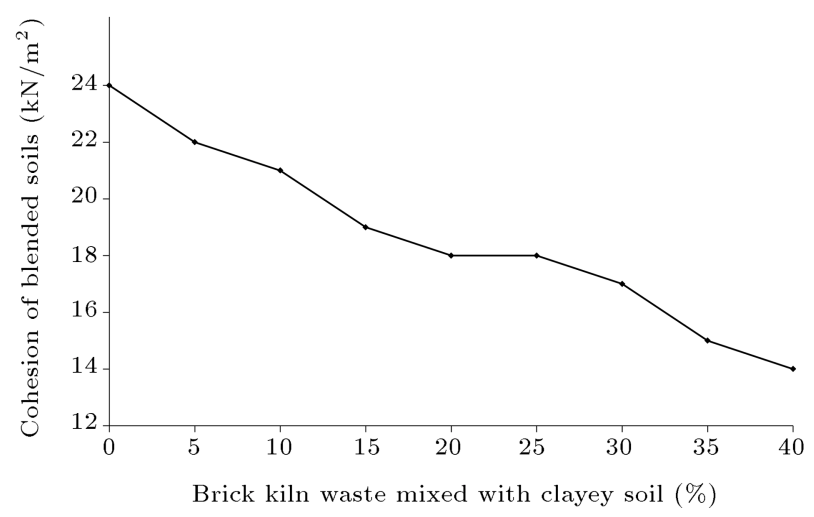

Figure 4. Effect of addition of brick kiln waste on the cohesion of clayey soil.

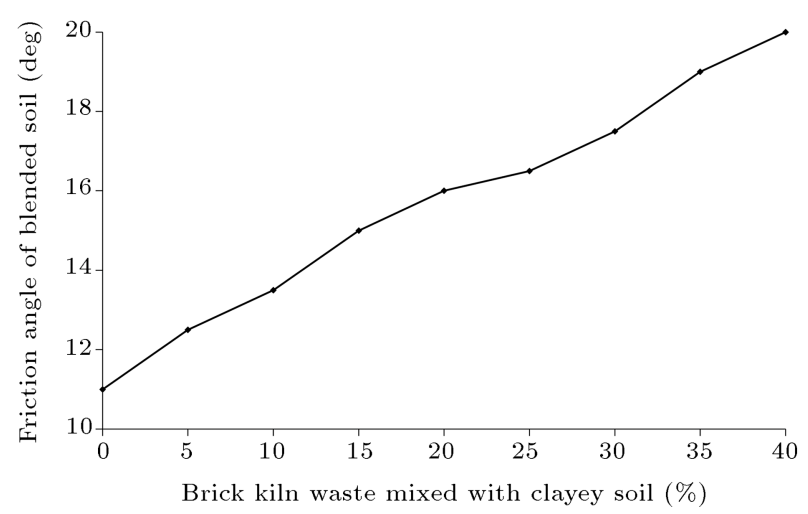

Figure 5. Effect of brick kiln waste on the friction angle of clayey soil.

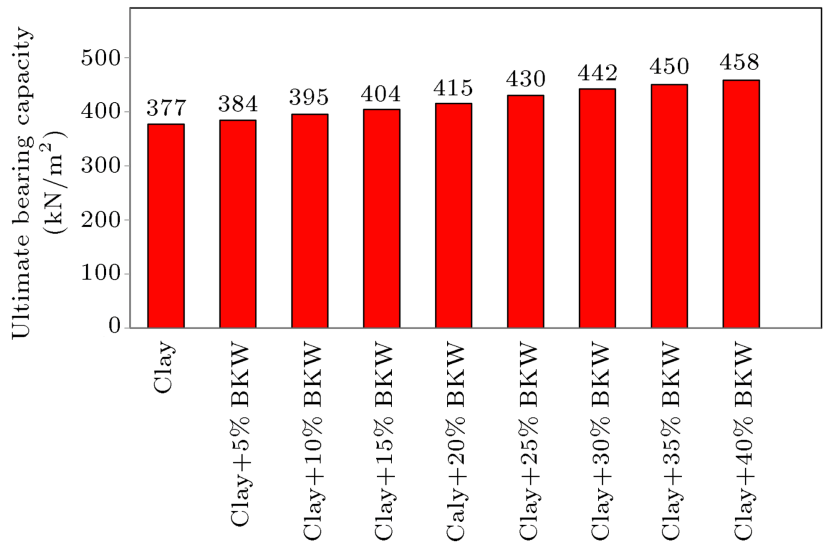

Figure 6. Ultimate bearing capacity of clayey soil blended with different proportions of Brick Kiln Waste (BKW).

isolated square footing of $2 \mathrm{~m} \times 2 \mathrm{~m}$ and depth of $2 \mathrm{~m}$ was calculated through Terzaghi's bearing capacity equation (see, e.g. [29]):

$$
q_{u}=c N c+\gamma D N q+0.5 \gamma B N \gamma,
$$

where $q_{u}, c, \gamma, D$, and $B$ are ultimate bearing capacity, cohesion, unit weight of the soil, depth of foundation, width of footing, respectively, and $N_{c}, N_{\gamma}, N_{q}$ are Terzaghi's bearing capacity factors.

The ultimate bearing capacity of the soils blended with the BKW is presented in Figure 6. The ultimate bearing capacity of the blended soils increased with an increase in the BKW. The ultimate bearing capacity of the clayey soil mixed with $40 \%$ BKW increased by $21 \%$. The ultimate bearing capacity of the clayey soil blended with $25 \%$ of the BKW was about $430 \mathrm{kPa}$. According to International Code Council [30], the ultimate bearing capacity of sandy gravel and/or gravel is about $430 \mathrm{kPa}$. This implies that the BKW can be utilized with clayey soil as a foundation material without compromise on bearing capacity.

\subsection{Effect of $B K W$ on the swelling properties of the clayey soil}

The free swell ratio of the blended soils decreased with an increase in the BKW (Figure 7). According to the criteria suggested by Prakash and Sridharan [26], the degree of expansion of clayey soil was moderate. With the addition of the BKW in the clayey soil up to $30 \%$, the expansion of the blended soil became low. Finally, the degree of expansion of the blended soils became negligible when mixed with $35 \%$ to $40 \%$ of the BKW.

\section{Conclusions}

In this study, the suitability of the Brick Kiln Waste (BKW) as a stabilizer for clayey soils was examined. The main findings of this study are summarized below: 


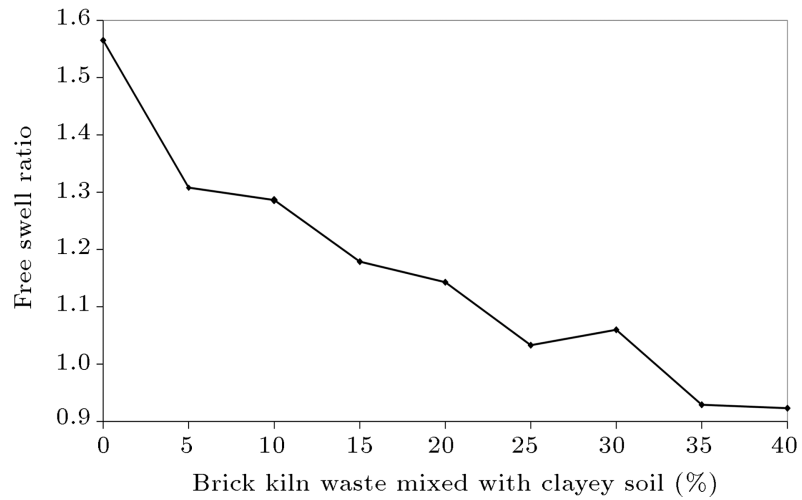

Figure 7. Decrease in free swell ratio of the clayey soil blended with 5 to $40 \%$ Brick Kiln Waste (BKW).

1. With the addition of the BKW, the clayey soil became coarser and more appropriate as a partial fill material for highways and foundations of buildings;

2. The dry density of the blended soil slightly reduced by $3 \%$ and $7 \%$ when the $20 \%$ and $40 \%$ values of BKW were added, respectively;

3. Values of cohesion and friction angle of the clayey soil were reduced and increased by $40 \%$ and $39 \%$, respectively, when the BKW added was $40 \%$ in value;

4. In comparison to clayey soil, the ultimate bearing capacity of the blended soils increased by $21 \%$ when the BKW mixed was $40 \%$ in value;

5. The results presented in this study suggest that the BKW could be utilized as a stabilizer for clayey soils to be used in highway embankments and foundations of buildings.

\section{Acknowledgements}

The authors would like to thank Quaid-e-Awam University of Engineering Science and Technology, Nawabshah for providing access to Soil Mechanics Laboratory for conducting the tests reported in this study.

\section{References}

1. Saeed, A. "Pakistan third largest brick- producing country in South Asia", Business Recorder (2017). https://fp.brecorder.com/2017/05/20170504175631.

2. Mortaheb, M.M. and Mahpour, A. "Integrated construction waste management, a holistic approach", Sci. Iran., 23(5), pp. 2044-2056 (2016).

3. Shah, A., Jan, I.U., Khan, R., and Qazi, E.U. "Exploring the opportunities for reuse of municipal Construction and Demolition (C\&D) wastes in concrete", Sci. Iran., 21(4), pp. 1317-1324 (2014).

4. Ehsani, M., Shariatmadaria, N., and Mirhosseini, S.M. "Experimental study on behavior of soil-waste tire mixtures", Sci. Iran., 24(1), pp. 65-71 (2017).
5. James, J., Lakshmi, S.V. and Pandian, P.K. "A preliminary investigation on the geotechnical properties of blended solid wastes as synthetic fill material", Int. J. Techn., 8(3), pp. 466-476 (2017).

6. Zhang, Y., Soleimanbeigi, A., Likos, W.J., and Edil, T.B. "Geotechnical and leaching properties of municipal solid waste incineration fly ash for use as embankment fill material", Transp. Res. Rec: J. Transp. Res. Bd., 2579, pp. 70-78 (2016).

7. James, J. and Pandian, P.K. "Industrial wastes as auxiliary additives to cement/lime stabilization of soils", Adv. Civ. Eng., 2016, pp. 1-17 (2016).

8. Sabat, A.K. and Pati, S. "A review of literature on stabilization of expansive soil using solid wastes", Electron. J. Geotech. Eng., 19(U), pp. 6251-6267 (2014).

9. Slack, R.J., Gronow, J.R., and Voulvoulis, N. "Household hazardous waste in municipal landfills: contaminants in leachate", Sci. Total. Environ., 337(1), pp. 119-137 (2005).

10. Idris, A., Inanc, B., and Hassan, M.N. "Overview of waste disposal and landfills/dumps in Asian countries", J. Mater. Cycles. Waste., 6(2), pp. 104-110 (2004).

11. Li, H., Zheng, X., Sheng, Y., and Ke, S. "Differential settlements of embankment treated by cement flyash gravel pile and sheet pile in freeway extension constructions", Int. J. Geomech., 17(11), 04017092, pp. 1-8 (2017).

12. Cui, W., Zheng, X., and Zhang, Q.Q. "Evaluation of bearing capacity of fly-ash highway subgrade based on model test", J. Test. Eval., 46(3), pp. 943-955 (2018).

13. Zhang, C., Jiang, G., Liu, X., and Wang, Z. "Deformation performance of cement-fly ash-gravel pilesupported embankments over silty clay of medium compressibility: a case study", Arab. J. Geosci, 8(7), pp. 4495-4507 (2015).

14. Sharma, N.K., Swain, S.K., and Sahoo, U.C. "Stabilization of a clayey soil with fly ash and lime: a micro level investigation", Geotech. Geol. Eng., 30(5), pp. 1197-1205 (2012).

15. Eberemu, A.O. "Consolidation properties of compacted lateritic soil treated with rice husk ash", Geomat., 1, pp. 70-78 (2011).

16. Kumar, A. and Gupta, D. "Behavior of cementstabilized fiber-reinforced pond ash, rice husk ash-soil mixtures", Geotext. Geomembranes., 44(3), pp. 466474 (2016).

17. Kumar, B.S. and Preethi, T.V. "Behavior of clayey soil stabilized with rice husk ash \& lime", Int. J. Eng. Tr. Tech., 11(1), pp. 44-48 (2014).

18. Chen, J.A. and Idusuyi, F.O. "Effect of Waste Ceramic Dust (WCD) on index and engineering properties of shrink-swell soils", Int. J. Eng. Mod. Tech., 1(8), pp. 52-61 (2015).

19. Ali, R., Khan, H., and Shah, A.A. "Expansive soil stabilization using marble dust and bagasse ash", Int. 
J. Sci. Res., 3(6), pp. 2812-2816 (2014).

20. Bhavsar, S.N. and Patel, A.J. "Analysis of swelling \& shrinkage properties of expansive soil using brick dust as a stabilizer", Int. J. Emerg. Tech. Adv. Eng., 4(12), pp. 303-308 (2014).

21. ASTM D422-63 "Standard test method for particlesize analysis of soils", ASTM International, West Conshohocken, PA (2007).

22. ASTM D4318-10 "Standard test methods for liquid limit, plastic limit, and plasticity index of soils", ASTM International, West Conshohocken, PA (2010).

23. AASHTO M 145:1991 (R2008) "Specification for classification of soils and soil-aggregate mixtures for highway construction purposes", American Association of State Highway and Transportation Officials (2008).

24. ASTM D1557-12 "Standard test methods for laboratory compaction characteristics of soil using modified effort $\left(56,000 \mathrm{ft}-\mathrm{lbf} / \mathrm{ft}^{3}\left(2,700 \mathrm{kN}-\mathrm{m} / \mathrm{m}^{3}\right)\right)$ ", ASTM International, West Conshohocken, PA (2012).

25. ASTM D3080/D3080M-11 "Standard test method for direct shear test of soils under consolidated drained conditions", ASTM International, West Conshohocken, PA (2011).

26. Prakash, K. and Sridharan, A. "Free swell ratio and clay mineralogy of fine-grained soils", Geotech. Test. J., 27(2), pp. 220-225 (2004).

27. Garber, N.J. and Hoel, L.A., Traffic and Highway Engineering, 5th Edn, Cengage Learning, Stamford, USA (2015).

28. Carter, M. and Bentley, S.P., Soil Properties and their Correlations, 2nd Edn., John Wiley \& Sons, Chichester, West Sussex, United Kingdom (2016).

29. Bowels, J.E., Foundation Analysis and Design, 5th Edn., The McGraw Hill companies, Inc., Singapore (2001).

30. ICC "International residential code for one and twofamily dwellings", International Code Council (2018).

\section{Biographies}

Abdullah Saand is a Professor at the Department of Civil Engineering, Quaid-e-Awam University of Engineering, Science, and Technology (QUEST), Nawabshah, Pakistan. He received PhD in Structural Engineering from University of Technology Malaysia in 2007. His research interests include polymer modified concrete, properties of construction materials, and concrete repair.

Muhammad Auchar Zardari received $\mathrm{PhD}$ from Lulea University of Technology, Lulea, Sweden in Soil Mechanics and Foundation Engineering in 2013. Presently, he is an Associate Professor at the Department of Civil Engineering, QUEST Nawabshah, Pakistan. His research interests include numerical modeling of geotechnical structures, long-term stability of embankment dams, internal erosion of dams, geotechnical properties of waterlogged soils, and soil stabilization.

Manthar Ali Keerio is a Professor at the Civil Engineering Department at QUCEST Larkano. He received $\mathrm{PhD}$ in Structural Engineering from QUEST Nawabshah in 2017. His research interests include supplementary cementing materials and self-consolidating concrete.

Sabir Hussain Shaikh has obtained a Master of Civil Engineering from QUEST Nawabshah in 2015. Presently he is working as Resident Engineer in Halcrow Pakistan, Pvt. Ltd. His research interests are soil stabilization with solid waste materials.

Daddan Khan Bangwar is a Professor in Civil Engineering Department at QUEST Nawabshah. He received $\mathrm{PhD}$ in Structural Engineering from QUEST Nawabshah in 2016. His research interests include supplementary cementing materials and polymer modified concrete. 